University of Wollongong

Research Online

Faculty of Engineering - Papers (Archive)

Faculty of Engineering and Information

Sciences

$1-1-2007$

\title{
Stability of Cementite formed from Hematite and Titanomagnetite Ore
}

\author{
Raymond J. Longbottom \\ Norwegian University of Science and Technology, rayl@uow.edu.au \\ Oleg Ostrovski \\ University of New South Wales \\ Jianqiang Zhang \\ University of New South Wales \\ David J. Young \\ University of New South Wales
}

Follow this and additional works at: https://ro.uow.edu.au/engpapers

Part of the Engineering Commons

https://ro.uow.edu.au/engpapers/1259

\section{Recommended Citation}

Longbottom, Raymond J.; Ostrovski, Oleg; Zhang, Jianqiang; and Young, David J.: Stability of Cementite formed from Hematite and Titanomagnetite Ore 2007, 175-184.

https://ro.uow.edu.au/engpapers/1259

Research Online is the open access institutional repository for the University of Wollongong. For further information contact the UOW Library: research-pubs@uow.edu.au 


\title{
Stability of Cementite Formed from Hematite and Titanomagnetite Ore
}

\author{
RAYMOND JAMES LONGBOTTOM, OLEG OSTROVSKI, JIANQIANG ZHANG, and \\ DAVID YOUNG
}

\begin{abstract}
The stability of cementite formed during the reduction of hematite and preoxidized titanomagnetite ores in a methane-hydrogen gas mixture was examined in the temperature interval $500{ }^{\circ} \mathrm{C}$ to $900{ }^{\circ} \mathrm{C}$ for the hematite ore and $300{ }^{\circ} \mathrm{C}$ to $1100{ }^{\circ} \mathrm{C}$ for titanomagnetite. Cementite formed from hematite ore was most stable at temperatures between $750{ }^{\circ} \mathrm{C}$ to $770{ }^{\circ} \mathrm{C}$. Its decomposition rate increased with decreasing temperature between $750{ }^{\circ} \mathrm{C}$ and $600{ }^{\circ} \mathrm{C}$ and with increasing temperature above $770{ }^{\circ} \mathrm{C}$. Cementite formed from preoxidized titanomagnetite was most stable in the temperature range $700{ }^{\circ} \mathrm{C}$ to $900{ }^{\circ} \mathrm{C}$. The rate of cementite decomposition increased with decreasing temperature between $700{ }^{\circ} \mathrm{C}$ and $400{ }^{\circ} \mathrm{C}$ and with increasing temperature above $900{ }^{\circ} \mathrm{C}$. Cementite formed from titanomagnetite ore was more stable than cementite formed from hematite under all conditions examined.
\end{abstract}

DOI: $10.1007 / \mathrm{s} 11663-006-9005-2$

(C) The Minerals, Metals \& Materials Society and ASM International 2007

\section{INTRODUCTION}

CEMENTITE formed from iron ore by the reaction of iron oxides with carbon supersaturated gases based on methane or carbon monoxide is metastable and decomposes to metallic iron and graphite, even under strongly carburizing atmospheres. ${ }^{[1-8]}$ The process of decomposition of cementite in direct reduction is akin to the metal dusting of iron-based alloys. The decomposition is thought to be triggered by deposition of carbon on the cementite surface (due to slow carbon diffusion in cementite).$^{[3-8]}$ This decreases the carbon activity at the carbon-cementite interface from the supersaturated gas value to $a_{\mathrm{C}}=1$. At this level, cementite is thermodynamically unstable and decomposes.

Nakagawa et al. ${ }^{[2]}$ and Zhang ${ }^{[1]}$ reported an unusual temperature dependence of the stability: the rate of cementite decomposition increased with decreasing temperature within a certain range. According to Zhang et al.,$^{[3-8]}$ in the range $500^{\circ} \mathrm{C}$ to $925^{\circ} \mathrm{C}$, cementite was most stable at temperatures close to $750{ }^{\circ} \mathrm{C}$. The rate of its decomposition increased with increasing temperature to $925^{\circ} \mathrm{C}$, but also with decreasing temperature from $730{ }^{\circ} \mathrm{C}$ to $750{ }^{\circ} \mathrm{C}$ to $550{ }^{\circ} \mathrm{C}$.

In the reduction of titanomagnetite ore reported earlier, ${ }^{[9]}$ the product cementite contains titanium. Titanium stabilizes cementite ${ }^{[9]}$ but no information is available for its effect on cementite decomposition during carbothermal reduction of titanomagnetite ore. The purpose of the present study was to develop an understanding of the effect of temperature and titanium on

RAYMOND JAMES LONGBOTTOM, Postdoctor, is with the Department of Materials Technology, Norwegian University of Science and Technology, 7491 Trondheim, Norway. Contact e-mail: rayuai@gmail.com OLEG OSTROVSKI, Head of School and Professor, JIANQIANG ZHANG, Research Associate, and DAVID YOUNG, Honorary Professor, are with the School of Metallurgical Engineering, University of New South Wales, Sydney, NSW 2052, Australia.

Manuscript submitted July 7, 2006.

Article published online May 5, 2007. cementite decomposition and stability. The behavior of cementite formed from titanomagnetite ore was compared with that of cementite formed from hematite ore.

\section{EXPERIMENTAL}

Cementite was formed by reducing hematite and preoxidized titanomagnetite ore in a flowing $\mathrm{CH}_{4}-\mathrm{H}_{2}-\mathrm{Ar}$ gas mixture, as described earlier. ${ }^{[9]}$ The compositions of the hematite ore and titanomagnetite ironsand are given in Table I. The titanomagnetite was preoxidized by heating in air within a muffle furnace at $1000{ }^{\circ} \mathrm{C}$ for 4 days. This converted the ore to the more easily reduced titanohematite.

Reduction and cementation of the ore and cementite decomposition were studied in a lab-scale fixed bed reactor in a vertical tube furnace. A schematic of the experimental reactor is shown in Figure 1. Mass flow controllers were used to control the gas composition used in the experiments, while the composition of the off-gas could be measured using a mass spectrometer.

Cementite samples were prepared by passing the reducing/carburizing gas with a composition of $35 \mathrm{vol}$ pct $\mathrm{CH}_{4}, 55$ pct $\mathrm{H}_{2}$, and 10 pct Ar through the sample bed at $750{ }^{\circ} \mathrm{C}$ for 15 minutes for the hematite ore and 30 minutes for the preoxidized titanomagnetite ore. The product was more than $98 \mathrm{wt}$ pct cementite containing a small amount of metallic iron. The temperature of the sample was then changed to the experimental value for cementite decomposition and the sample held for a prescribed period of time. The time taken for the temperature to change was about 15 minutes. After decomposition, the sample was subsequently lifted to the cold zone and quenched under argon. Decomposition of cementite formed from titanomagnetite was studied under both the $\mathrm{CH}_{4}-\mathrm{H}_{2}-\mathrm{Ar}$ reducing/carburizing atmosphere and an inert Ar atmosphere.

The extent of cementite decomposition was measured by determining the phase constitution of quenched 
Table I. Composition of Iron Ores (Weight Percent)

\begin{tabular}{lccccccccc}
\hline Ore & $\mathrm{Fe}(\mathrm{Tot})$ & $\mathrm{SiO}_{2}$ & $\mathrm{Al}_{2} \mathrm{O}_{3}$ & $\mathrm{TiO}_{2}$ & $\mathrm{P}$ & $\mathrm{CaO}$ & $\mathrm{K}_{2} \mathrm{O}$ & $\mathrm{S}$ & $\mathrm{MgO}$ \\
\hline Mt. Whaleback & 62.7 & 5.35 & 3.61 & 0.09 & 0.087 & 0.016 & 0.03 & 0.028 & - \\
NZ ironsand & 57.2 & 2.17 & 3.59 & 7.43 & - & 0.67 & - & - & 2.94 \\
\hline
\end{tabular}

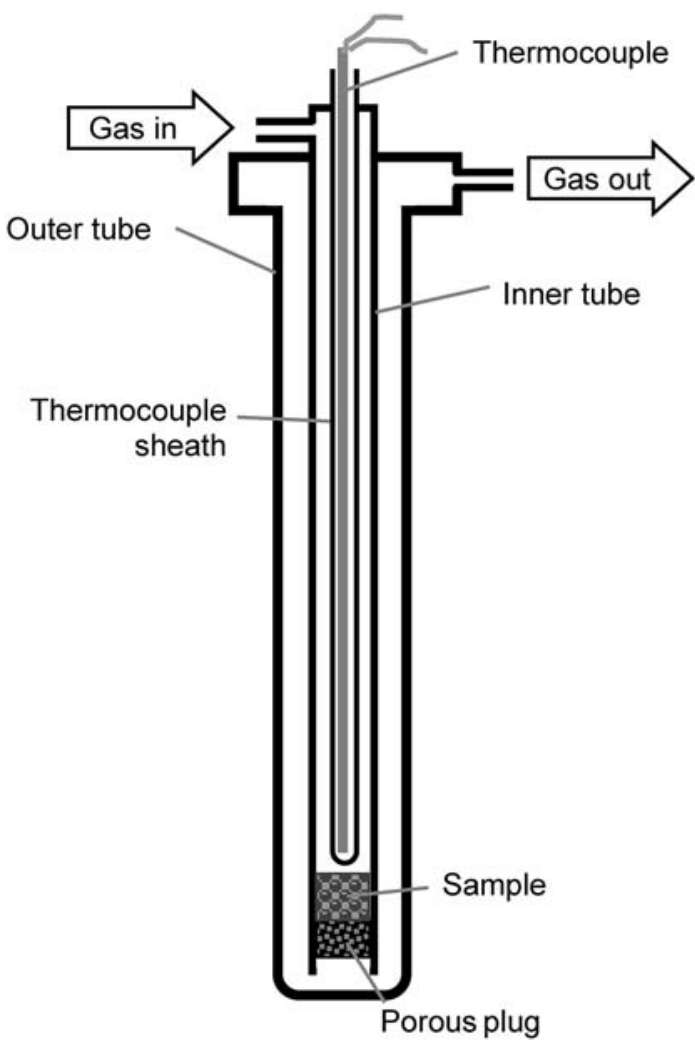

Fig. 1-Schematic diagram showing the reactor used for experiments.

samples quantitatively by X-ray diffraction (XRD) using a copper $K_{\alpha}$ source. The XRD measurements of the iron and cementite phases were validated using Mössbauer analysis, as described by Park et al. ${ }^{[10]}$

The morphology of reacted samples was examined by both optical microscopy and scanning electron microscopy (SEM). Optical microscopy was carried out on specimens of cementite after decomposition to different extents. These samples were prepared by mounting in resin, metallographically polishing, and etching in basic sodium picrate, which selectively stains cementite a dark brown.

\section{RESULTS}

Analysis by XRD of decomposed cementite revealed the presence of remnant $\mathrm{Fe}_{3} \mathrm{C}$, metallic iron, and graphite. No iron oxides were observed under the reducing conditions used, and no titanium compounds were detected. The weight fraction of remnant $\mathrm{Fe}_{3} \mathrm{C}$ determined from the XRD analysis was used as a measure of the extent of reaction.

The decomposition kinetics of hematite-derived cementite in $\mathrm{CH}_{4}-\mathrm{H}_{2}-\mathrm{Ar}$ gas are shown in Figure 2 (a)

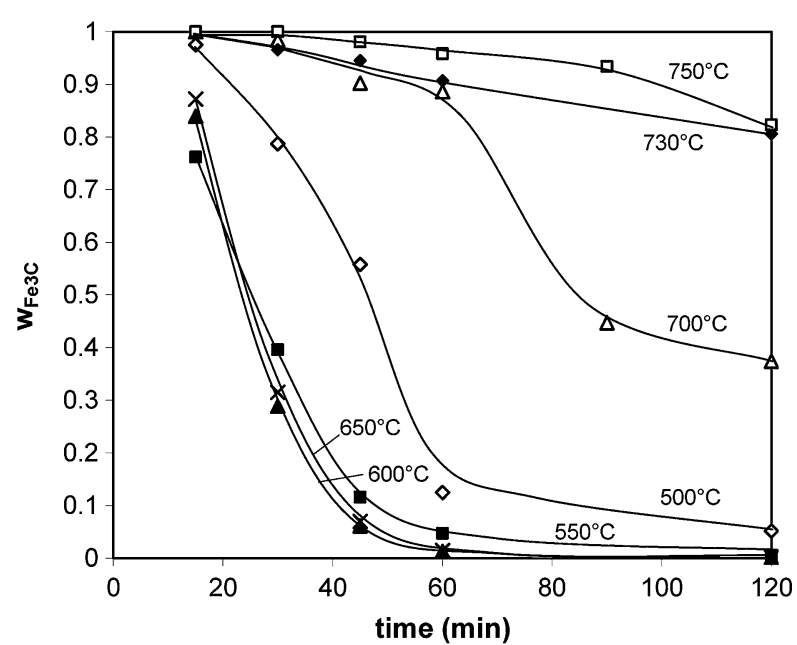

(a)

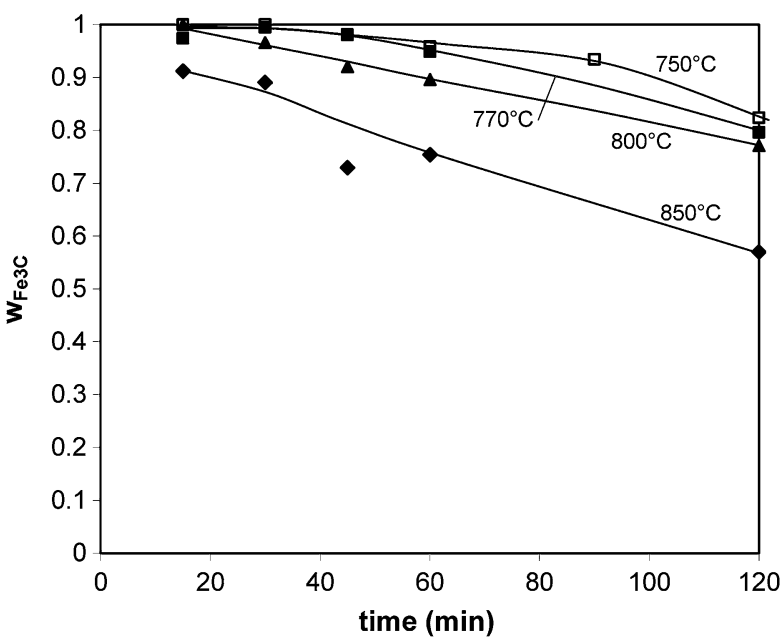

(b)

Fig. 2-Mass fractions of cementite formed from hematite during decomposition at different temperatures: (a) from $500{ }^{\circ} \mathrm{C}$ to $750{ }^{\circ} \mathrm{C}$ and (b) from $750{ }^{\circ} \mathrm{C}$ to $850{ }^{\circ} \mathrm{C}$.

for temperatures below $750{ }^{\circ} \mathrm{C}$ and in Figure 2(b) for temperature above $750{ }^{\circ} \mathrm{C}$. The corresponding results for the decomposition of cementite derived from preoxidized titanomagnetite are shown in Figures 3(a) and (b). Decomposition of the same material under pure argon proceeded according to the kinetics shown in Figure 4. The decomposition rates are compared in Figure 5, where the fraction of $\mathrm{Fe}_{3} \mathrm{C}$ remaining after 1 hour of decomposition is used as the comparison measure.

Cementite decomposition rates were calculated from the slopes of the kinetic curves reported in Figures 1 through 3 . Early stage rates $(t=15$ minutes $)$ are shown in Figure 6. 


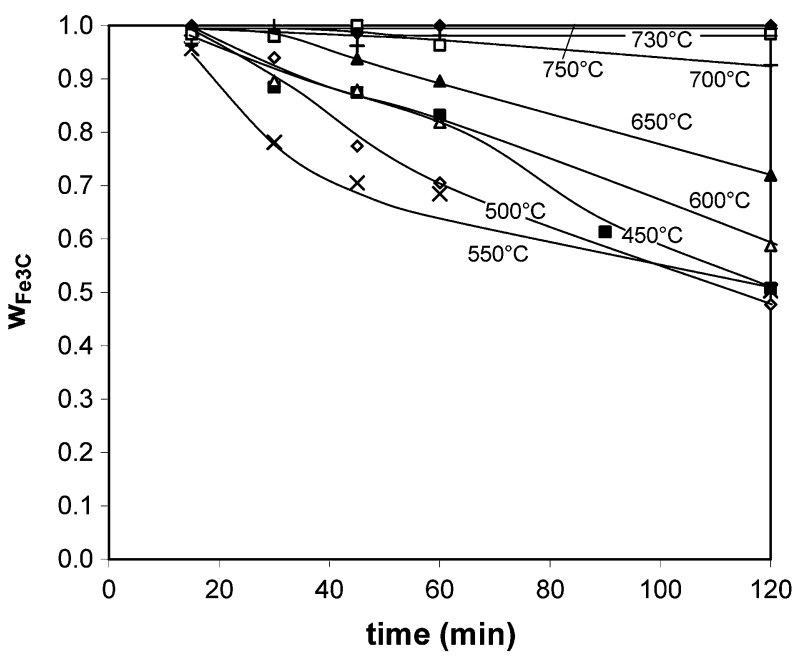

(a)

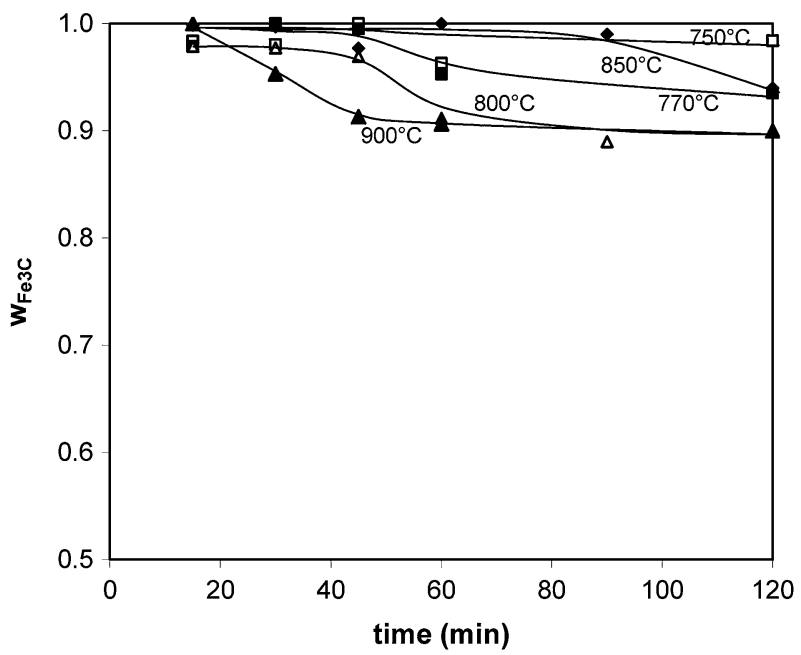

(b)

Fig. 3-Mass fractions of cementite formed from preoxidized titanomagnetite during the process of decomposition under a carburizng atmosphere at different temperatures: (a) from $450{ }^{\circ} \mathrm{C}$ to $750{ }^{\circ} \mathrm{C}$ and (b) from $750{ }^{\circ} \mathrm{C}$ to $900{ }^{\circ} \mathrm{C}$.

Etched cross sections of cementite particles formed from the hematite ore and decomposed at different temperatures are shown in Figure 7. Metallic iron precipitated along the edges of the particles and along the large pores, forming either blocks or seams of metallic iron within the cementite. Metallic iron exhibited some coarsening, in comparison to the cementite, due to sintering after precipitation. The amount of metallic iron found within the particles at different times matched the XRD results. Thus, there was more iron visible, for the same decomposition time, at $600{ }^{\circ} \mathrm{C}$ than at $500{ }^{\circ} \mathrm{C}$, while at $750{ }^{\circ} \mathrm{C}$ (60 minutes) and $800{ }^{\circ} \mathrm{C}$ (30 minutes), metallic iron was not observed.

Figure 8 shows cross sections of cementite formed from the preoxidized titanomagnetite ore decomposed at different temperatures. Iron was again observed around the edges of the particles. Iron was also detected within the cementite interior at lower temperatures, but

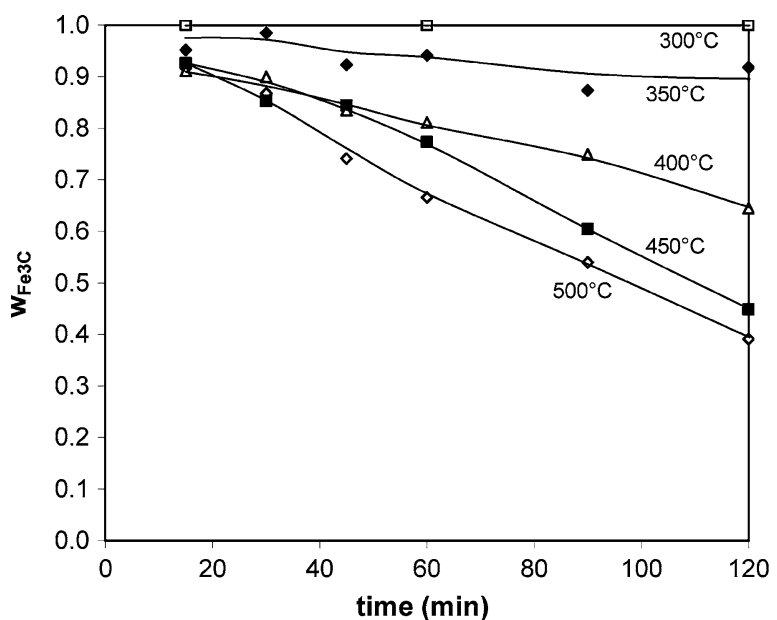

(a)

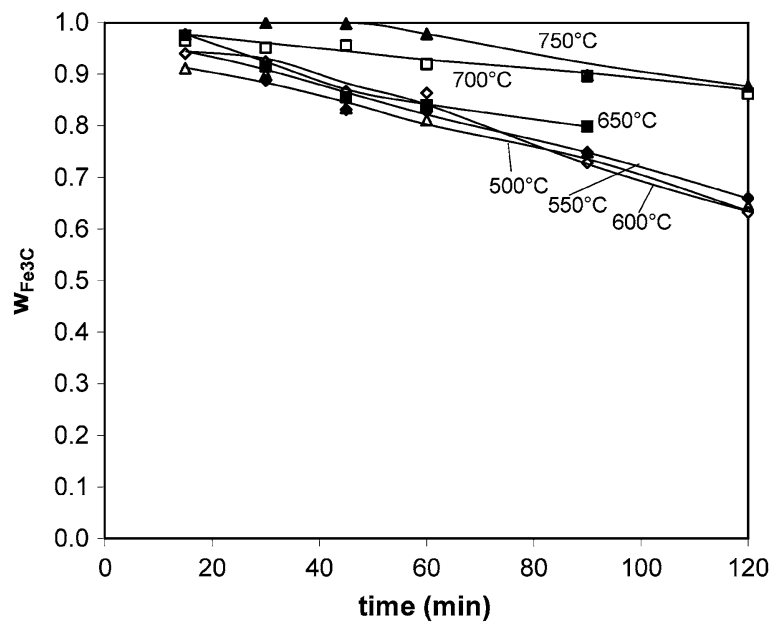

(b)

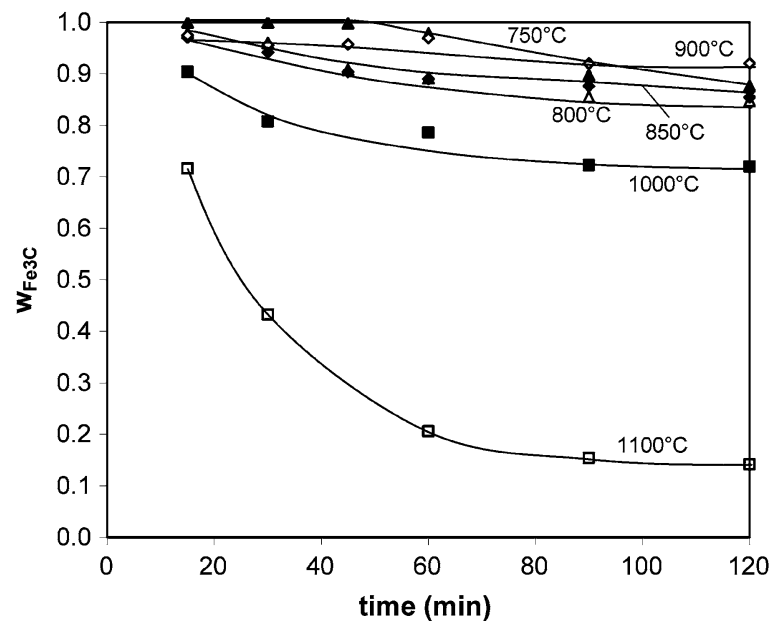

(c)

Fig. 4-Mass fractions of cementite formed from preoxidized titanomagnetite during decomposition under an inert atmosphere at different temperatures: (a) from $300{ }^{\circ} \mathrm{C}$ to $500{ }^{\circ} \mathrm{C},(b)$ from $550{ }^{\circ} \mathrm{C}$ to $750{ }^{\circ} \mathrm{C}$, and $(c)$ from $750{ }^{\circ} \mathrm{C}$ to $1100^{\circ} \mathrm{C}$.

generally not at high temperatures. This morphological change differed from that seen in the decomposition of cementite formed from the hematite ore. 


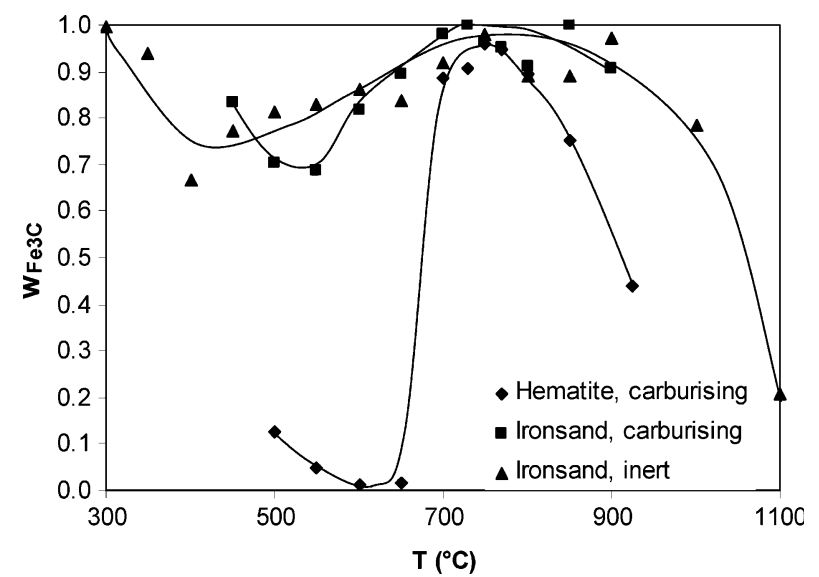

Fig. 5-Mass fractions of cementite formed from preoxidized titanomagnetite and hematite ore after 60-min decomposition under both carburizing and inert atmospheres.

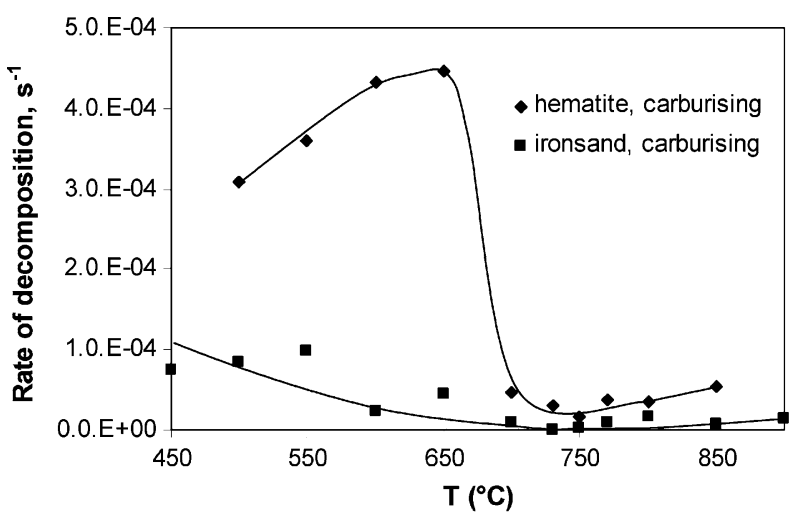

(a)

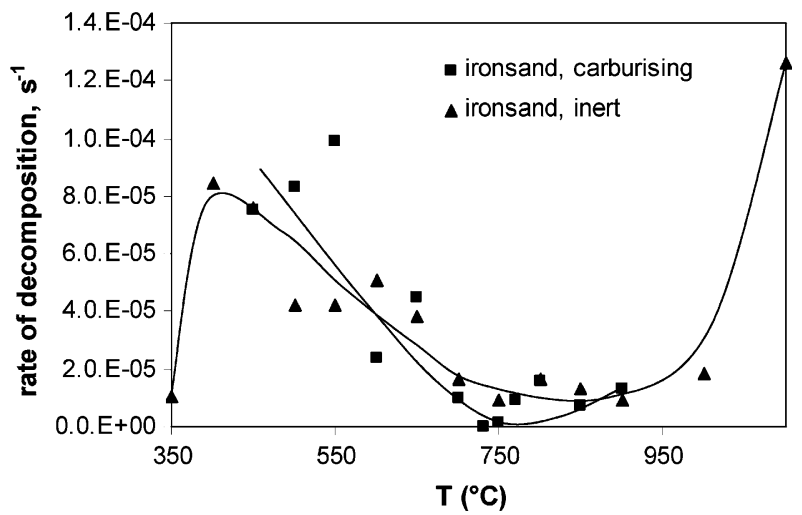

(b)

Fig. 6-Rate of decomposition of cementite formed from (a) hematite and preoxidized titanomagnetite ores in the carburizing atmosphere and $(b)$ preoxidized titanomagnetite ore in the carburizing and inert gas atmospheres.

At temperatures between $700{ }^{\circ} \mathrm{C}$ and $850{ }^{\circ} \mathrm{C}$, when the decomposition of cementite formed from the preoxidized titanomagnetite was slow, iron nucleated around the edges of the particle. As the temperature decreased, and the decomposition of cementite became faster, metallic iron nucleated throughout the sample.

\section{DISCUSSION}

The decomposition behavior of hematite-derived cementite was generally in agreement with that reported by Zhang et al. ${ }^{[7,8]}$ The cementite was most stable at about $730{ }^{\circ} \mathrm{C}$ to $750{ }^{\circ} \mathrm{C}$. At higher temperatures, the decomposition rate increased with increasing temperature. From $600{ }^{\circ} \mathrm{C}$ to $650{ }^{\circ} \mathrm{C}$, to $730{ }^{\circ} \mathrm{C}$ to $750{ }^{\circ} \mathrm{C}$, the decomposition rate increased with decreasing temperature, until a maximum rate was reached at $600{ }^{\circ} \mathrm{C}$ to $650{ }^{\circ} \mathrm{C}$. Below this range, the decomposition rate decreased with decreasing temperature.

As seen in Figures 5 and 6, the behavior of titanomagnetite (ironsand) derived cementite in $\mathrm{CH}_{4}-\mathrm{H}_{2}-\mathrm{Ar}$ gas was qualitatively similar, although decomposition rates were much slower. The titanium modified cementite was most stable at around $750{ }^{\circ} \mathrm{C}$ to $770{ }^{\circ} \mathrm{C}$ (Figure 3(b)), and its decomposition increased only slightly at higher temperatures. Between $550{ }^{\circ} \mathrm{C}$ and $750{ }^{\circ} \mathrm{C}$, the rate increased with decreasing temperature to a maximum, below which decomposition slowed at lower temperatures.

The behavior of the titanium modified cementite in argon gas was rather similar to that in $\mathrm{CH}_{4}-\mathrm{H}_{2}-\mathrm{Ar}$ gas, as seen in Figure 6(b). In this case, additional data were obtained at higher temperatures and the decomposition rate found to increase rapidly with temperature above about $950{ }^{\circ} \mathrm{C}$.

In order to understand the temperature effects on $\mathrm{Fe}_{3} \mathrm{C}$ decomposition, it is necessary to consider both the thermodynamics and the kinetics of the cementite decomposition reaction. In principle, two possible reactions are available:

$$
\mathrm{Fe}_{3} \mathrm{C}+2 \mathrm{H}_{2}=3 \mathrm{Fe}+\mathrm{CH}_{4}
$$

and

$$
\mathrm{Fe}_{3} \mathrm{C}=\mathrm{Fe}+\mathrm{C}
$$

where, in both cases, $\mathrm{Fe}$ is an iron-carbon saturated solution, either austenite at $T>727^{\circ} \mathrm{C}$ or ferrite at lower temperature.

\section{A. Thermodynamics of Cementite Decomposition}

The standard Gibbs free energies of Reactions [1] and [2] differ according to whether the iron phase is $\gamma$-austenite $\left(T>727^{\circ} \mathrm{C}\right)$ or $\alpha$-ferrite $\left(T<727^{\circ} \mathrm{C}\right)^{[11]}$ and are listed subsequently:

$$
\begin{gathered}
\Delta \mathrm{G}_{1, \gamma}^{\mathrm{o}}=-98,633+119.74 \mathrm{~T}(\mathrm{~J}) \\
\Delta \mathrm{G}_{1, \alpha}^{\mathrm{o}}=-116,436+136.77 \mathrm{~T}(\mathrm{~J}) \\
\Delta \mathrm{G}_{2, \gamma}^{\mathrm{o}}=-11,234+11.0 \mathrm{~T}(\mathrm{~J}) \\
\Delta \mathrm{G}_{2, \alpha}^{\mathrm{o}}=-29,037+28.0 \mathrm{~T}(\mathrm{~J})
\end{gathered}
$$



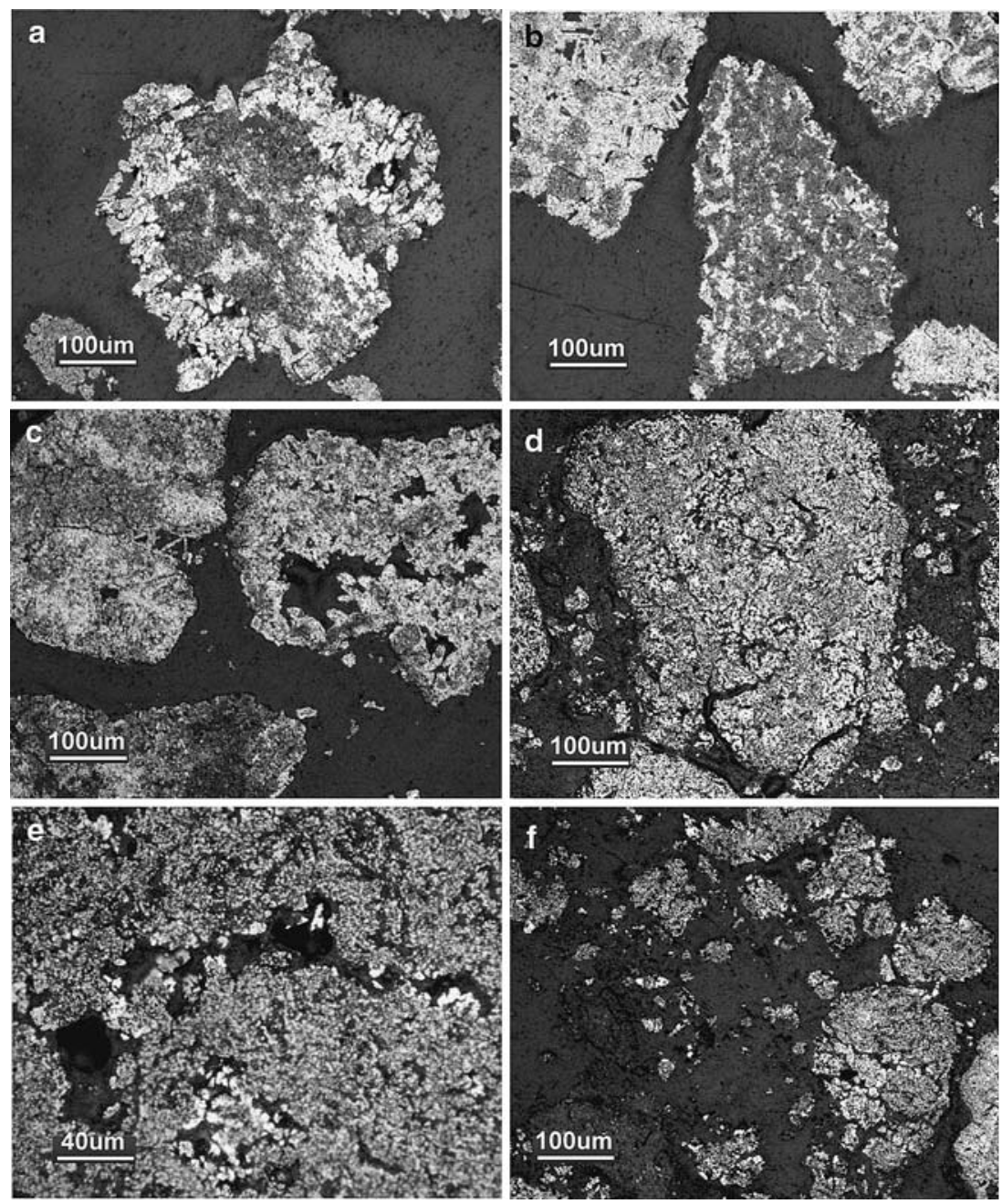

Fig. 7-Cross sections of cementite formed from the hematite ore and decomposed at different temperatures: $(a) 500{ }^{\circ} \mathrm{C}, 30 \mathrm{~min}, 100$ times; $(b)$ $500{ }^{\circ} \mathrm{C}, 60 \mathrm{~min}, 100$ times; (c) $600{ }^{\circ} \mathrm{C}, 30 \mathrm{~min}, 100$ times; (d) $750{ }^{\circ} \mathrm{C}, 60 \mathrm{~min}, 100$ times; $(e) 750{ }^{\circ} \mathrm{C}, 60 \mathrm{~min}, 300$ times; and $(f) 800{ }^{\circ} \mathrm{C}, 30$ min, 100 times.

Consider first Reaction [1] in the low-temperature ferrite regime. If the small carbon solubility in iron is neglected and the approximation $a_{\mathrm{Fe}}=1$ is adopted, it is found that $\Delta G_{1, \alpha}=0$ at $T=571{ }^{\circ} \mathrm{C}$ for the gas composition employed (35 vol pct $\mathrm{CH}_{4}$ and $55 \mathrm{vol}$ pct $\mathrm{H}_{2}$ ). Thus, cementite is predicted to decompose at lower temperatures, but to be stable with respect to the carburizing gas at $T>571{ }^{\circ} \mathrm{C}$. This is illustrated graphically in Figure 9, where the value of $a_{\mathrm{C}}$, as calculated from the supposed equilibrium

$$
\mathrm{CH}_{4}=\mathrm{C}+2 \mathrm{H}_{2}
$$

for which

$$
\Delta \mathrm{G}^{\mathrm{o}}=87,397-108.7 \mathrm{~T}(\mathrm{~J})
$$

is compared with that calculated from Eqs. [4a] and $[4 b]$.

In evaluating $a_{\mathrm{C}}$ from Eq. [3a], the iron activity in carbon saturated austenite can be calculated from the thermodynamic model developed in Mogutnov et al.:.[12]

$$
\begin{aligned}
\log a_{\mathrm{Fe}, \gamma}= & 1 / 4 \log \left((1-5 \mathrm{xC}) /\left(1-\mathrm{x}_{\mathrm{C}}\right)\right) \\
& -158 / \mathrm{T}\left[\mathrm{xC}^{2} /\left(1-\mathrm{x}_{\mathrm{C}}\right)^{2}\right]
\end{aligned}
$$

where $x_{\mathrm{C}}$ is the carbon mole fraction estimated from the $\mathrm{Fe}-\mathrm{C}$ phase diagram. The carbon activity of a supersaturated $\mathrm{CH}_{4}-\mathrm{H}_{2}-\mathrm{Ar}$ gas exceeds that required to stabilize $\mathrm{Fe}_{3} \mathrm{C}$ at $T>571{ }^{\circ} \mathrm{C}$. Nonetheless, cementite was found to decompose at all temperatures in the experimental range $500{ }^{\circ} \mathrm{C}$ to $900{ }^{\circ} \mathrm{C}$. It is, therefore, concluded that Eq. [1] does not reflect the reaction pathway, that gassolid equilibrium is not achieved, and that cementite decomposition occurs via Eq. [2], despite the high carburizing potential of the ambient gas. In this case, the driving force for reaction is given by Eq. [4] at $a_{\mathrm{C}}=1$. This was confirmed by the XRD analysis results, which showed that graphite was produced during cementite decomposition.

Reaction [2] is a phase transformation. It can occur in successive steps,

$$
\mathrm{Fe}_{3} \mathrm{C}=3 \mathrm{Fe}(\mathrm{C})
$$



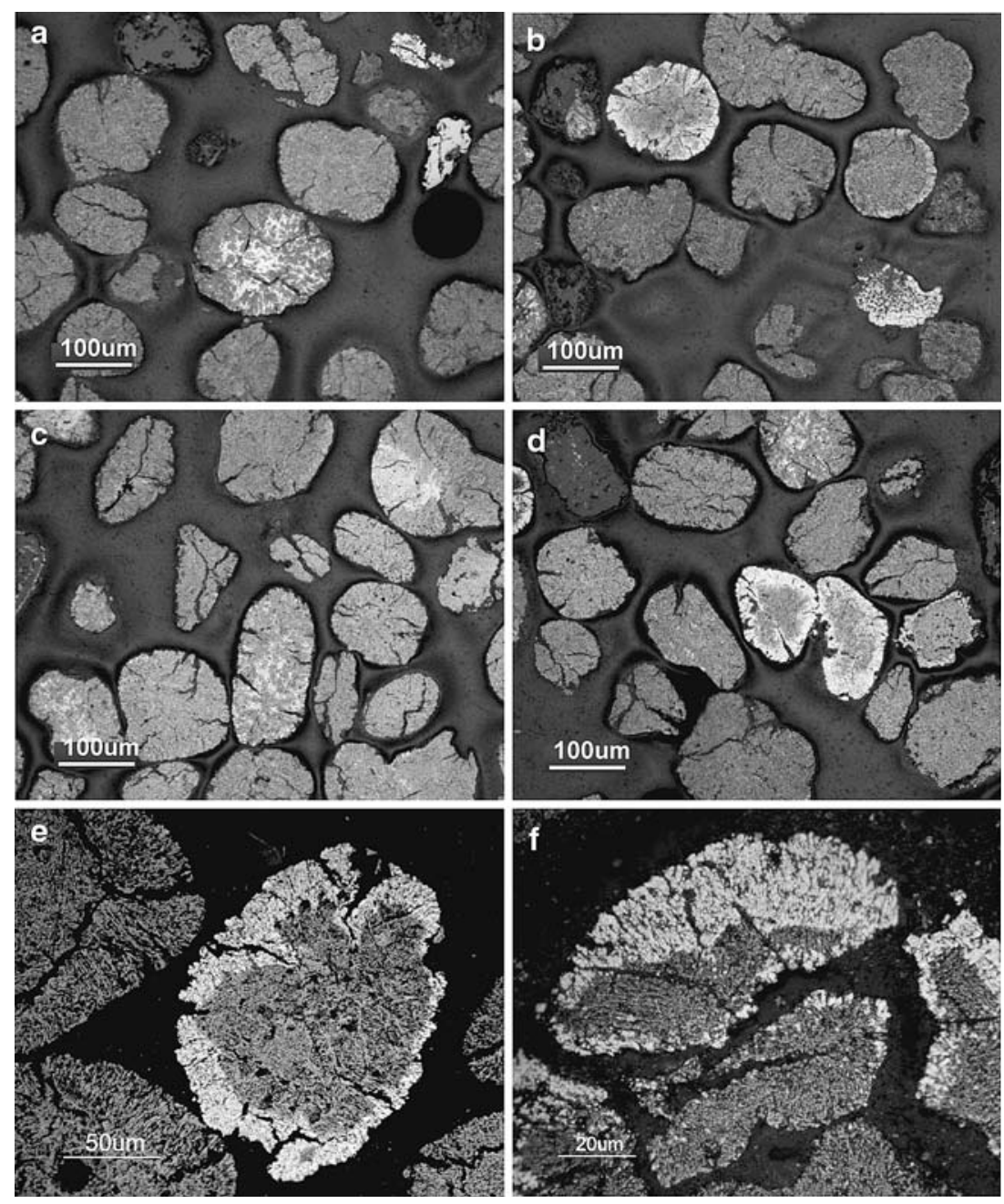

Fig. 8- Cementite formed from preoxidized titanomagnetite ore at $750{ }^{\circ} \mathrm{C}$, decomposed at different temperatures: $(a) 400{ }^{\circ} \mathrm{C}$, 120 min, 100 times; (b) $400{ }^{\circ} \mathrm{C}, 120 \mathrm{~min}, 100$ times; (c) $600{ }^{\circ} \mathrm{C}, 120 \mathrm{~min}, 100$ times; (d) $600{ }^{\circ} \mathrm{C}, 120 \mathrm{~min}, 100$ times; (e) $750{ }^{\circ} \mathrm{C}, 60 \mathrm{~min}, 200$ times; and (f) $750{ }^{\circ} \mathrm{C}, 90 \mathrm{~min}, 500$ times.

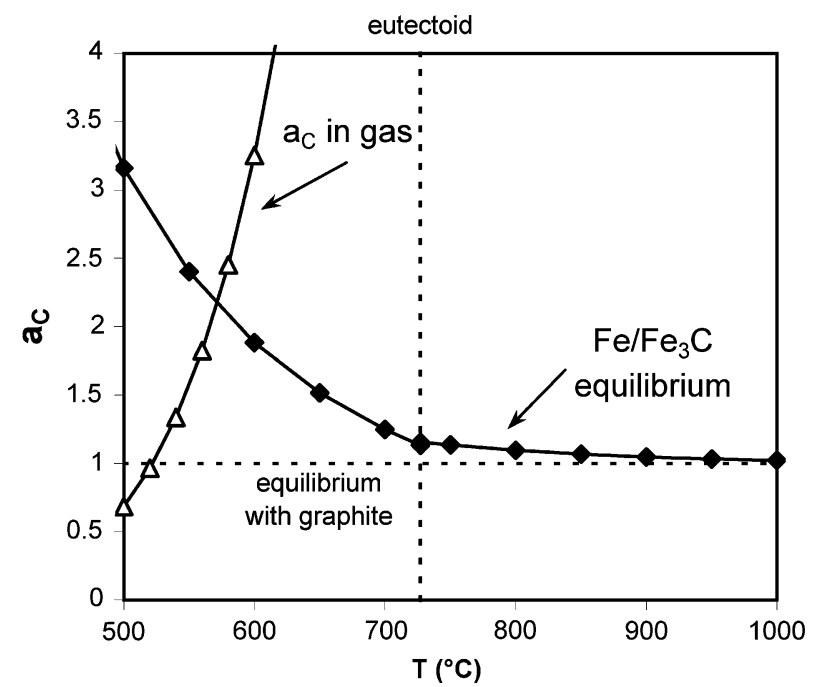

Fig. 9-Equilibrium carbon activity in cementite as a function of temperature.

$$
\mathrm{Fe}(\mathrm{C})=\mathrm{Fe}+\mathrm{C}
$$

where $\mathrm{Fe}(\mathrm{C})$ represents carbon supersaturated iron, or directly via the single step process represented by Eq. [2]. In either case, the process involves nucleation and growth of the product iron phase within the cementite. The kinetics of such processes are generally described by the Avrami equation: ${ }^{[13]}$

$$
F=1-\exp \left(-k t^{n}\right)
$$

where $F$ is the fraction transformed in time $t$. Here, $k$ represents both nucleation and growth rates, and hence is strongly temperature dependent. The value of the index $n$ reflects the nucleation mechanism. The log-log plots in Figure 10 show that $f_{\mathrm{Fe}_{3} \mathrm{C}}=1-F$ decays with time, in agreement with Eq. [10]. However, $n$ varies with temperature, being 2 to 3 at temperatures of $500{ }^{\circ} \mathrm{C}$ to $700{ }^{\circ} \mathrm{C}$ and 1 to 2 at higher temperatures. This indicates a change in nucleation mechanism. 


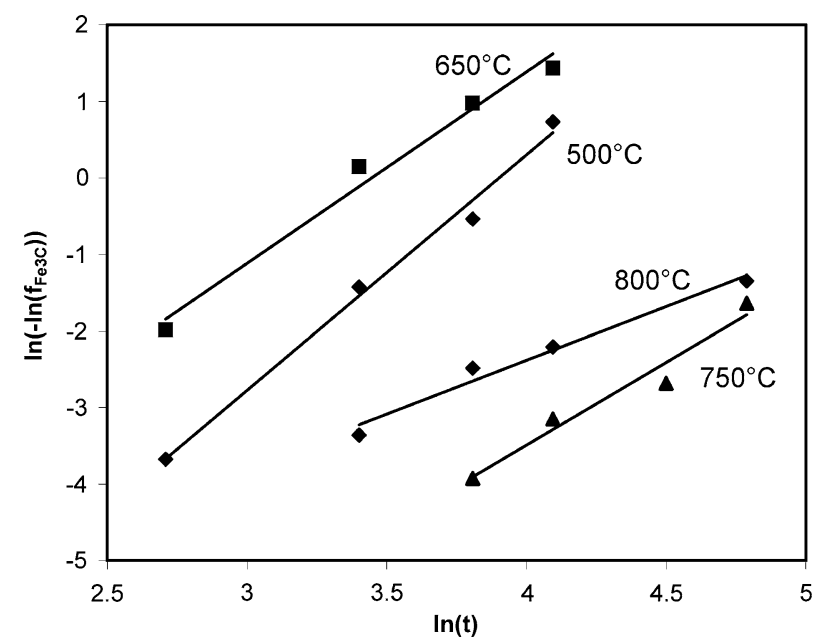

Fig. 10-Plot of $\ln (t)$ against $\ln \left(-\ln \left(f_{\mathrm{Fe}_{3} \mathrm{C}}\right)\right)$, showing behavior in accordance with Eq. [10].

The kinetic data in Figures 2-4 were used to construct the temperature-time-transformation (TTT) curves shown in Figure 11. It is seen that at temperatures below $730{ }^{\circ} \mathrm{C}$ to $750{ }^{\circ} \mathrm{C}$, the curves have the " $\mathrm{C}$ " shape characteristic of many solid-state phase transformations. At temperatures above about $750{ }^{\circ} \mathrm{C}$, the cementite transformation rate increases with increasing temperature. The TTT curves change their form at a temperature near the austenite-ferrite transition temperature of $727^{\circ} \mathrm{C}$. The Gibbs free energy change driving the $\mathrm{Fe}_{3} \mathrm{C}$ decomposition becomes more negative as the temperature decreases (Eqs. [4a] and [4b]). This tends to increase the rate of both nucleation and growth. However, growth kinetics are supported by diffusion, which slows as the temperature is lowered.

Taking the example of carbon diffusion through ferrite as the rate-controlling step, we can write for the process illustrated in Figure 12

$$
\text { Rate }=D_{\mathrm{Fe}, \alpha}\left(C^{\mathrm{Fe}_{3} C / \mathrm{Fe}, \alpha}-C^{C / \mathrm{Fe}, \alpha}\right)
$$

where $C^{\mathrm{Fe}_{3} C / \mathrm{Fe}, \alpha}$ and $C^{C / \mathrm{Fe}, \alpha}$ are carbon concentrations at the cementite-ferrite and graphite-ferrite interface, $D_{\mathrm{Fe}, \alpha}$ is the carbon diffusion coefficient, and variation in the diffusion path length is ignored. The concentration of carbon is related to its activity by an activity coefficient $\gamma_{\mathrm{C}}$ :

$$
a_{C}=\gamma_{C} C
$$

which will be approximated as constant. With $a_{\mathrm{C}}=1$ at the iron-graphite interface, Eqs. [11] and [12] yield

$$
\text { Rate }=D_{\mathrm{Fe}, \alpha}\left(a_{C}^{\mathrm{Fe}_{3} C / \mathrm{Fe}, \alpha}-1\right) / \gamma_{C}=
$$

$$
\mathrm{D}_{\mathrm{o}} \exp (-Q / \mathrm{R} T)\left[\exp \left(-\Delta \mathrm{G}_{2, \alpha}^{\mathrm{o}} / \mathrm{R} T\right)-1\right] / \gamma_{\mathrm{C}}
$$

where $Q$ is the diffusion activation energy. Equation [14] explains the form of the TTT curve in the ferrite temperature regime. Indeed, using Eq. [15] from Wert ${ }^{[14]}$ for

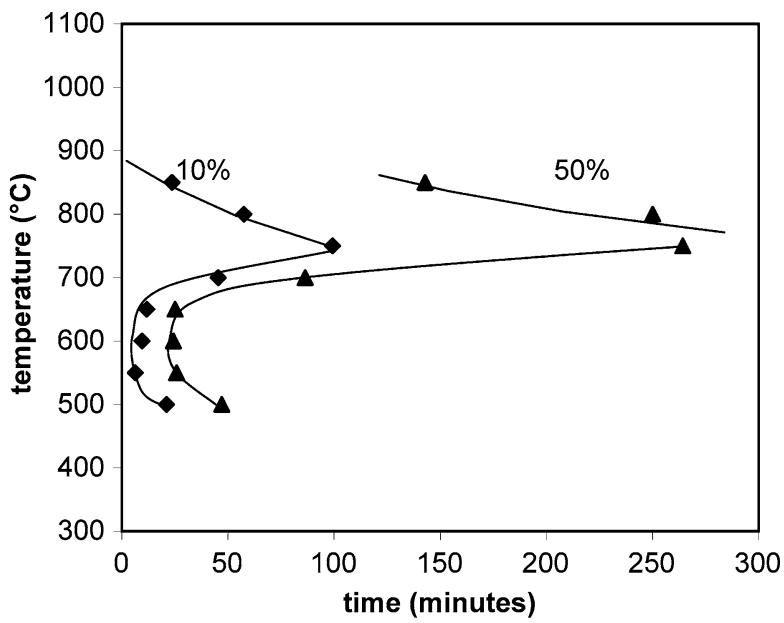

(a)

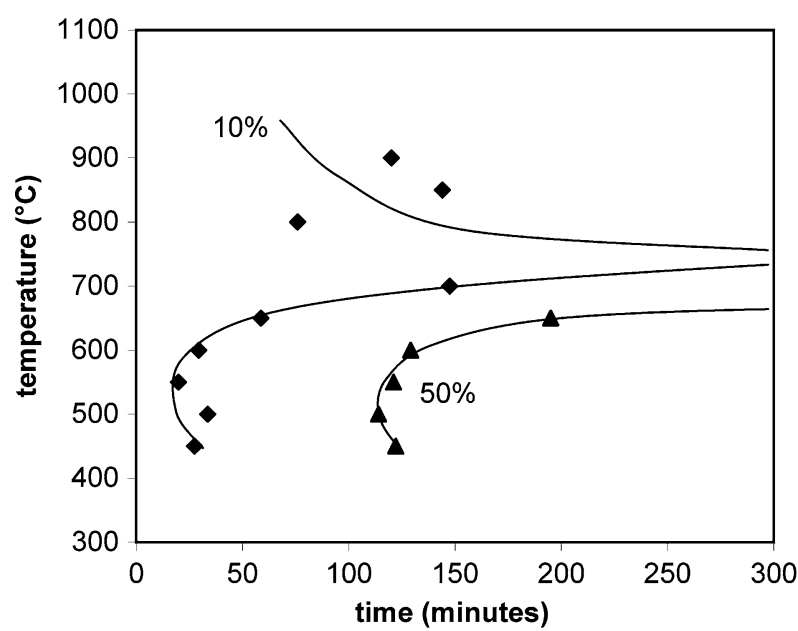

(b)

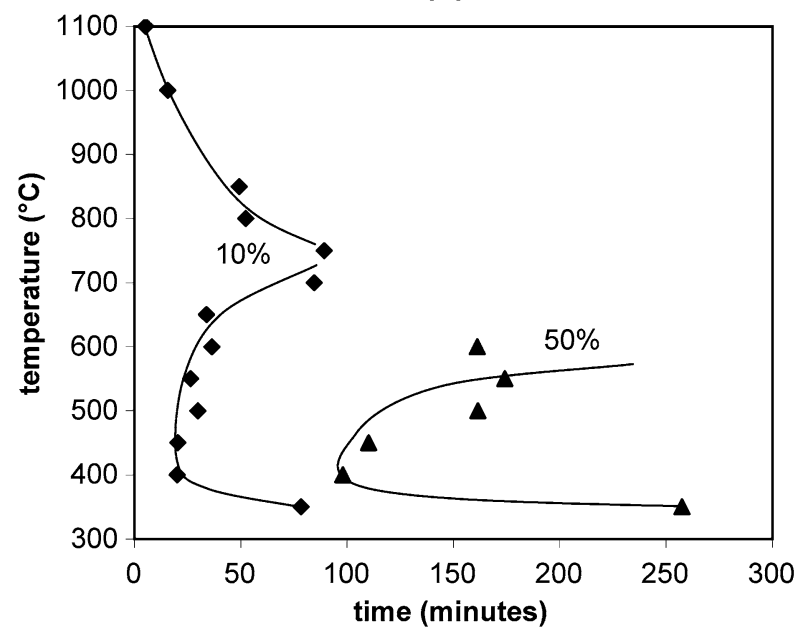

(c)

Fig. 11-TTT diagrams for the decomposition of cementite formed from iron ore under different atmospheres, for 10 pct decomposition on the left (diamonds) and 50 pct decomposition on the right (squares). (a) Hematite ore, carburizing atmosphere; $(b)$ preoxidized titanomagnetite, carburizing; and $(c)$ preoxidized titanomagnetite, inert atmosphere.

calculation of $D_{\mathrm{Fe}-\alpha}$ and Eq. [4b] for calculation of carbon activity, the change in the rate of cementite decomposition with temperature can be described by Eq. [16]. 


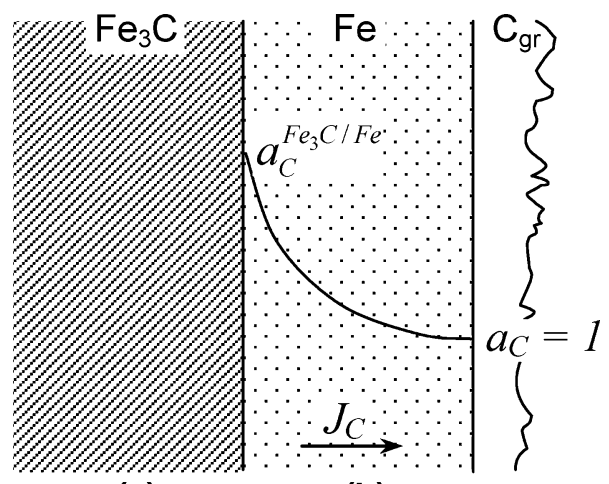

(a)

(b)

Fig. 12 - Possible mechanism for cementite decomposition: (a) $\mathrm{Fe}_{3} \mathrm{C}$ $\rightarrow 3 \mathrm{Fe}+\underline{\mathrm{C}}$ and $(b) \underline{\mathrm{C}} \rightarrow \mathrm{C}_{(g r)}$.

$$
\begin{gathered}
D_{a-\mathrm{Fe}}=0.02 \exp \left(-\frac{10,115}{T}\right) \\
\text { Rate }=0.02 R_{a} \exp \left(\frac{-10,115}{T}\right) \\
\exp \left(\left(\frac{-29,037+28 T}{\mathrm{R} T}\right)-1\right)
\end{gathered}
$$

where $R_{\alpha}$ is a temperature-independent constant.

The rate of cementite decomposition calculated in this way has a maximum at $600{ }^{\circ} \mathrm{C}$ to $650{ }^{\circ} \mathrm{C}$, as shown in Figure 13, in very good agreement with experimental observation.

Equation [13] also explains the change in the TTT curve at the austenite-ferrite transition temperature: it results from differences in the diffusion coefficient and the Gibbs free energy for austenite and ferrite.

A similar calculation for the austenite phase yields a different result. The carbon diffusion coefficient in austenite is described by Eq. [17] from Tibbets: ${ }^{[15]}$

$$
D_{\gamma-\mathrm{Fe}}=0.47 \exp (-1.6 c) \exp \left(-\frac{37,000-6600 c}{\mathrm{R} T}\right)
$$

where $c$ is carbon concentration in weight percent. The rate of cementite decomposition in the austenite region can be calculated from Eq. [18], which is similar to Eq. [13]:

$$
\text { Rate }=\mathrm{R}_{\gamma} D_{\mathrm{Fe}, \gamma}\left(a_{C}^{\mathrm{Fe}_{3} C / \mathrm{Fe}, \gamma}-1\right)
$$

where $R_{\gamma}$ is a temperature-independent coefficient.

In this case, the rate of cementite decomposition increases with increasing temperature, shown in Figure 14.

The carbon activity at the cementite/austenite interface changes relatively slowly, from 1.15 at the eutectoid temperature $727{ }^{\circ} \mathrm{C}$ to 1.02 at the eutectic temperature $1147{ }^{\circ} \mathrm{C}$, while the diffusion coefficient increases from $0.141 \times 10^{-7} \mathrm{~cm}^{2} \mathrm{~s}^{-1}$ to $46.1 \times 10^{-7} \mathrm{~cm}^{2} \mathrm{~s}^{-1}$ in the same

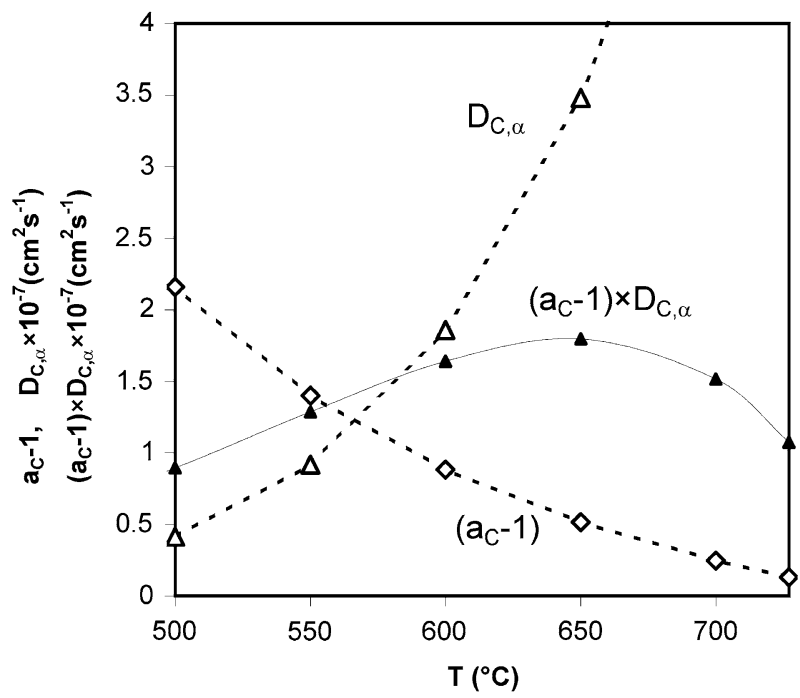

Fig. 13-Changes with temperature of the diffusion coefficient of carbon in ferrite, $D_{\mathrm{C}, \alpha}$, the activity of carbon at equilibrium between cementite and ferrite, $a_{\mathrm{C}}$, and the product $\left(a_{C}-1\right) \times D_{C, \alpha}$.

temperature interval. This change in $D$ determines the change in the rate of cementite decomposition with temperature.

It is seen from Figure 11 that the rate at which $\mathrm{Fe}_{3} \mathrm{C}$ produced from titanomagnetite decomposes is insensitive to the gas phase carbon activity. This confirms that Reaction [2] describes the process rather than Reaction [1].

The $\mathrm{C}$ shape of the TTT curve can again be explained on the basis of the mechanism illustrated in Figure 12. More generally, it can be attributed to the nucleation and growth kinetics of phase transformation. The effect of temperature on phase transformation can be described in the case of heterogeneous nucleation by the following equation: ${ }^{[13]}$

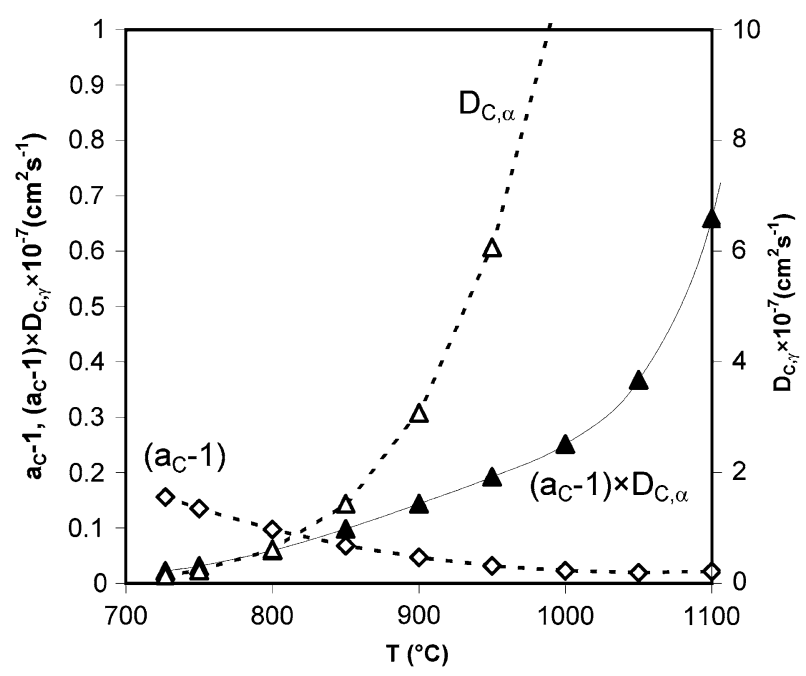

Fig. 14 - Changes with temperature of the diffusion coefficient of carbon in austenite, $D_{\mathrm{C}, \gamma}$, the activity of carbon at equilibrium between cementite and austenite, $a_{\mathrm{C}}$, and the product $\left(a_{C}-1\right) \times D_{C, \gamma}$. 

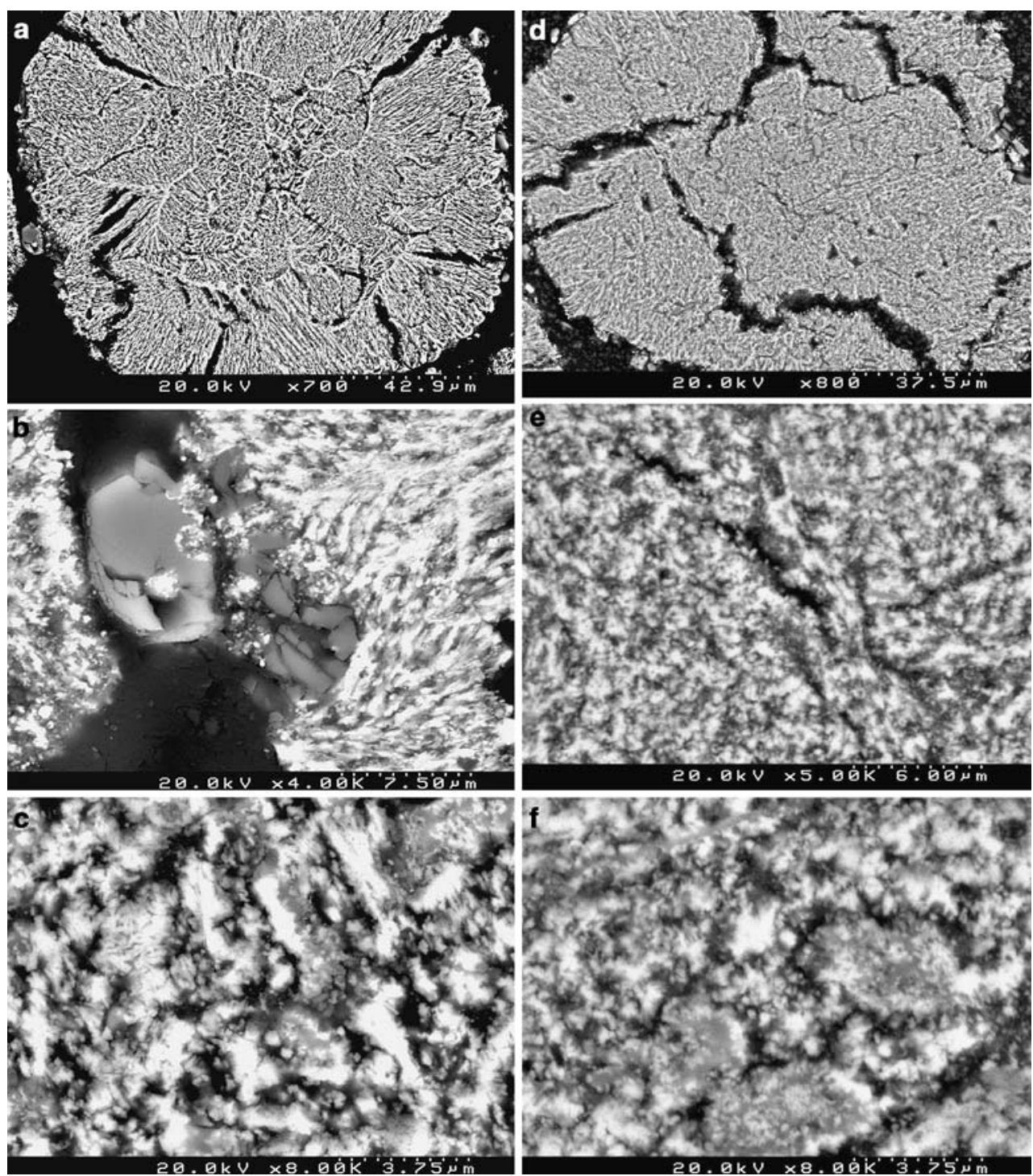

Fig. 15-The SEM/EDS analysis of cementite formed from preoxidized titanomagnetite ore decomposed at $500{ }^{\circ} \mathrm{C}$. (a) Low-magnification SEM image of cementite particle; $(b)$ medium-magnification SEM image of edge of cementite particle; $(c)$ high-magnification SEM image of interior of cementite particle, decomposed for $60 \mathrm{~min}$; (d) low-magnification SEM image of cementite particle; (e) medium-magnification SEM image of interior of cementite particle; and $(f)$ high-magnification SEM image of interior of cementite particle, decomposed for 120 min.

$$
\text { Rate }=\omega C_{o} \exp \left(-\frac{Q_{m}}{\mathrm{k} T}\right) \exp \left(-\frac{\Delta \mathrm{G}^{*}}{\mathrm{k} T}\right)
$$

where $\omega$ is a factor that takes into account the vibration frequency of the atoms, the shape, and the surface area of the critical nucleus; $C_{\mathrm{o}}$ is the number of nucleation sites per unit volume; $Q_{m}$ is the activation energy for atomic migration; and $\Delta G^{*}$ is the total Gibbs free energy change corresponding to the nucleus with a critical radius $r^{*}$, or the activation energy for the nucleation reaction.

For a nucleus with a critical radius $r^{*}, \Delta G^{*}$ becomes ${ }^{[13]}$

$$
\Delta G^{*}=\frac{16 \pi \gamma^{3}}{3\left(\Delta G_{V}-\Delta G_{S}\right)^{2}} \cdot S
$$

where $S$ is a shape factor appropriate to the nucleus geometry, $\gamma$ is the surface Gibbs free energy, $\Delta G_{V}$ is the
Gibbs free energy of the reaction, and $\Delta G_{S}$ is the misfit strain energy. The change in $\gamma$ and $\Delta G_{S}$ with temperature is relatively small.

The Gibbs free energy change of cementite decomposition increases with decreasing temperature, while the change in $\Delta G_{m}$ can be neglected. Therefore, the change in the cementite decomposition rate with temperature depends on the relationship between the "thermodynamic" and "diffusive" terms in Equation [19].

\section{B. Decomposition of Cementite Formed from Preoxidized Titanomagnetite Ore}

Cementite formed from preoxidized titanomagnetite ore is more stable than hematite-derived cementite, particularly at temperatures above $750{ }^{\circ} \mathrm{C}$. It was also observed that the temperature interval in which the decomposition rate increased with decreasing 
Table II. Titanium-Iron Ratio of Phases within Cementite Formed from Preoxidized Titanomagnetite Ore (EDS Analysis)

\begin{tabular}{llr}
\hline Sample & Point & Fe:Ti \\
\hline 0-min decomposition, $750{ }^{\circ} \mathrm{C}$ & bright phase & 10.36 \\
& & 13.71 \\
& gray phase & 4.49 \\
& & 7.00 \\
60-min decomposition, $500{ }^{\circ} \mathrm{C}$ & bright phase & 6.75 \\
& & 11.82 \\
& gray phase & 1.65 \\
120-min decomposition, 500 ${ }^{\circ} \mathrm{C}$ & bright phase & 11.66 \\
& & 10.49 \\
& gray phase & 2.11 \\
\hline
\end{tabular}

temperature was $750{ }^{\circ} \mathrm{C}$ to $400{ }^{\circ} \mathrm{C}$ for the titanomagnetite-derived cementite and $750{ }^{\circ} \mathrm{C}$ to $600{ }^{\circ} \mathrm{C}$ for the "hematite" cementite.

The SEM and EDS analysis of cementite formed from preoxidized titanomagnetite ore in the process of decomposition at $500{ }^{\circ} \mathrm{C}$ under the carburizing atmosphere is presented in Figure 15. The EDS analysis of cementite formed from preoxidized titanomagnetite is shown in Table II. Titanium in reduced/carburized titanomagnetite ore was detected in three main phases: (1) the dense oxide phase, consisting of gangue materials; (2) the gray phase, identified as titanium-rich irontitanium oxide dispersed in cementite with a relatively high titanium concentration compared to the bulk material; and (3) the bright phase, which is either cementite or metallic iron formed in the process of cementite decomposition, with a titanium content of 7 to 9 at. pct, which is the average for the particle. No titanium carbide phase was observed, although its formation has been reported in the literature. ${ }^{[16,17,18]}$

Titanium is known to be a strong carbide former, and even a small amount of titanium in the alloy may have a significant impact on the thermodynamic properties of the carbide formed. Titanium would reduce the activity of carbon in cementite, thereby decreasing the decomposition rate (Eq. [13]) and stabilizing cementite.

\section{CONCLUSIONS}

The decomposition of cementite formed from hematite and preoxidized titanomagnetite ores was investigated in the temperature range from $500{ }^{\circ} \mathrm{C}$ to $925^{\circ} \mathrm{C}$ for hematite under a carburizing atmosphere, and from $300{ }^{\circ} \mathrm{C}$ to $1100{ }^{\circ} \mathrm{C}$ for titanomagnetite ore under inert and carburizing atmospheres.

Cementite formed from hematite was most stable at $730{ }^{\circ} \mathrm{C}$ to $750{ }^{\circ} \mathrm{C}$. At temperatures between $750{ }^{\circ} \mathrm{C}$ and $600{ }^{\circ} \mathrm{C}$, the rate of cementite decomposition increased with decreasing temperature. Decomposition occurred with the highest rate at $600{ }^{\circ} \mathrm{C}$ to $650{ }^{\circ} \mathrm{C}$. At temperatures higher than $750{ }^{\circ} \mathrm{C}$ and lower than $600{ }^{\circ} \mathrm{C}$, the rate of cementite decomposition increased with temperature.

Titanium in the titanomagnetite cementite was found in three main phases: in a dense oxide (gangue) phase; in a titanium-iron oxide phase finely dispersed within the cementite, which was enriched with titanium; and in the cementite/metallic iron itself. Decomposition rates of titanomagnetite derived cementite were much slower. This cementite was most stable at $750{ }^{\circ} \mathrm{C}$ to $770{ }^{\circ} \mathrm{C}$ and its decomposition increased only slightly at higher temperatures. Between $550{ }^{\circ} \mathrm{C}$ and $750{ }^{\circ} \mathrm{C}$, the rate decreased with decreasing temperature to a maximum, below which decomposition slowed at lower temperatures.

The cementite decomposition rate was qualitatively described by kinetics of carbon transfer through austenite or ferrite formed in the decomposition reaction. This mechanism explains the $\mathrm{C}$ shape of the TTT curves in the ferrite region and increasing decomposition rate with increasing temperature in the austenite region.

The higher stability of cementite formed in the reduction of titanomagnetite ore was attributed to titanium in cementite, which decreases carbon activity in this phase, and consequently its decomposition rate.

\section{REFERENCES}

1. J. Zhang: Ph.D. Thesis, University of New South Wales, Sydney, June 2000.

2. H. Nakagawa, T. Murayama, and Y. Ono: Tetsu-to-Hagané, 1996, vol. 82 , pp. 261-66.

3. J. Zhang, O. Ostrovski, and K. Suzuki: Metall. Mater. Trans. B, 2000, vol. 31B, pp. 1139-42.

4. J. Zhang, O. Ostrovski, K. Suzuki: Belton Memorial Symp. Proc., 2000, Sydney, pp. 431-43.

5. J. Zhang and O. Ostrovski: 59th Ironmaking Conf. Proc., ISS, Warrendale, PA, 2000 pp. 339-49.

6. J. Zhang and O. Ostrovski: MINPREX 2000 Proc., 2000, pp. 50917.

7. J. Zhang and O. Ostrovski: Iron Steel Inst. Jpn. Int., 2001, vol. 41, pp. 333-39.

8. J. Zhang and O. Ostrovski: Iron Steel Inst. Jpn. Int., 2001, vol. 41, pp. $340-44$.

9. R. Longbottom, O. Ostrovski, and E. Park: Iron Steel Inst. Jpn. Int., 2006, vol. 46, pp. 641-46.

10. E. Park, J. Zhang, S. Thomson, O. Ostrovski, and R. Howe: Metall Trans B, 2001, vol. 32B, pp. 839-45.

11. E.T. Turkdogan: Physical Chemistry of High Temperature Technology, Academic Press, New York, NY, 1980.

12. B.M. Mogutnov and I.A. Tomilin: Shvartsman L.A. Thermodynamics of Iron Alloys, Metallurgy, Moscow, 1984.

13. D.A. Porter and K.E. Easterling: Phase Transformations in Metals and Alloys, Chapman and Hall, London, 1992.

14. C.A. Wert: Phys. Rev., 1950, vol. 79, pp. 601-05.

15. G.G. Tibbets: J. Appl. Phys., 1980, vol. 51, pp. 4813-16.

16. E. Park and O. Ostrovski: Iron Steel Inst. Jpn. Int., 2004, vol. 44, pp. 74-81.

17. E. Park and O. Ostrovski: Iron Steel Inst. Jpn. Int., 2003, vol. 43, pp. 1316-25.

18. H. Ohtani, T. Tanaka, M. Hasebe, and T. Nishizawa: CALPHAD, 1988, vol. 12, pp. 225-46. 